\title{
Мери Момировска
}

Институт за македонски јазик „Крсте Мисирков“, Скопје

\section{Дијалектолошката перспектива на микротопонимијата претставена преку материјал од Крушевскиот регион (во Република Македонија)}

Крушевскиот регион е сместен во централниот дел на РМ. Опфаќа 1 градска и 23 селски населби. Има интересна географска конфигурација, главно ридско-планинска и е особено богат извор на топонимиски материјал. Овој регион е и еден од мултиетничките региони во Македонија, во којшто живеат: Македонци, Власи, Албанци, Турци, Санџаклии, Македонци-муслимани, Срби, Хрвати, Роми. Меѓутоа, макротопонимите и микротопонимите од овој регион сведочат автохтоноста на словенското односно македонското население на овие простори.

Крушевскиот говор спаѓа во западномакедонското наречје, во групата на централните говори, поточно во прилепско-битолската група како дел од прилепскиот говор [Видоески 1998: 32]. Во неговата топонимија се одразени сите фонетско-фонолошки, морфонолошки, морфолошки, лексички и синтаксички особености кои се карактеристични за него.

1. Акцентот во крушевскиот говор, како и во целото западно наречје, е една од неговите најзначајни црти и претставува иновативен модел кој е единствен во словенскиот јазичен ареал. Во повеќесложните зборови тој е фиксиран на третиот слог од крајот на зборот, пр.: Бадн'ичииа, Дуг'азиияа, Цуи'улина, Шобурки. Покрај ова, акцентот има синтагматски карактер, т.е. има широки можности за образување на акцентски целости кај двокомпонентните топоними кога втората компонента е двосложна или едносложна, пр.: Ал'е-Чука, Бел'а-Вода, Н'ад-Дабје.

2. Вокалниот систем во крушевскиот говор е петочлен /и, е, о, у, a/ + силабемата $/ p /$. Вокалите имаат јасен изговор, како во акцентирана, така и во неакцентирана позиција. Пр.: Кад'иов-Дап, Лака, Лединка, Пато преку $K p^{\prime} y ш к a$. Кај топонимите со иницијално вокално /p/, силабичната вредност стои пред сонантот: 'Рвеник, 'Ржишта, 'Рто. 
3. Консонантскиот систем на крушевскиот говор се одликува со неколку специфичности:

- фонемата /x/ се изгубила само во иницијална позиција (пр.: 'Оцоско Ma:ло, $P^{\prime} и д о, У_{м}^{\prime}$ 'алиште), а во другите позиции е заменета со со фонемата /в/ (пр.: Сува-Река, Суво-Поле, 'Ореф);

- фонемата /л/ подлежи на редукција [Пјанка 1970: 291], односно во изговорот се доближува кон /y/ кога е во позиција пред консонант или кога е во финална позиција (пр.: Балалтин, Дол Леска, Јабел);

- полумеко /л / се јавува во позиција пред вокалите од заден ред /a, $\mathbf{0}, \mathbf{y} /$ (пр.: Велј'аница, К'ољо: Кл'аінче, Суљьо-Рет, 'Улјарник);

- старото палатално /н/ во поголем број топоними затврднало (пр: Буч'и-Камен, Голем'а-Нива, Н'ивата Јофческа, Пот-Камен);

- појава на секундарно меко /н/ како резултат од партиципацијата на мекоста од претходниот слог, којашто графички не се бележи (пр: Б'елушки Вод'еіниии, Прис'о-нй, Бран'еіница, Кам'еіница, Рв'еінии);

- интервокалното /в/ редовно се губи (пр: Барл'е-ца < Барлевица, Вез'енко: < Везенково, В'иро- < Вирови, М'аркоец < Марковеи), со исклучок на топонимите образувани од придавката $c y b,-a,-o,-u$, каде што интервокалното /в/ се чува (пр: Св'ополе, Сува Ледина, Сув'а-Река, Сув'а-Чешма);

- фонемата /в/ редовно се губи и во придавските суфикси -овски/-евски $(<-о в /-е в+-c \kappa u)$, при што варијантните суфикси -оски/-ески се сметаат за дијалектна разновидност на оние со /в/ (пр.: Дулеско М'а:ло, Ѓорески 'Oграѓ, Тасеск'о-Чешме);

- фонемата /ф/, покрај тоа што се јавува како резултат од обезвучувањето на /в/, се јавува уште и во топоними кои содржат позајмени зборови, односно лексеми од туѓо потекло (пр.: Фазл'ица, Ф'урна, Фудб'алиште);

- фонемата /џ/ главно се среќава кај топоними образувани од зборови од турско потекло (пр.: Аииоск'и-Нивје, Довлеиик, Кај Џам'ијана, Кои'а-Чешмa);

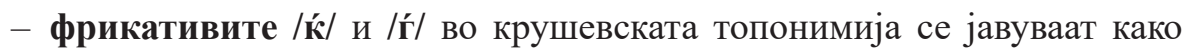
континуанти на прасловенските консонантски групи *tj и * $\mathbf{d j}$ (пр.: Б'уjкуќк,

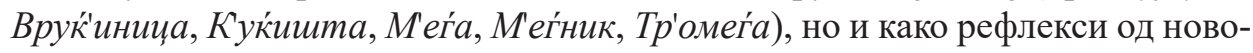
то јотување на групите -mj-, -дj-<-mьj-, -дьj- (пр.: Бр'аќa, Гр'амаѓe, ЛТиваѓe, Meŕe).

4. Гласовни процеси потврдени во крушевската топонимија се:

- асимилација на вокалите во секвенците /ea/, /oa/, /eo/, која е последица од губењето на интервокалните консонанти и којашто може да биде прогресивна (пр.: Блаж'е:-Чешма < Блажее < Блажеа < Блажева, Бој'о:-Нu$в а<$ Бојоо $<$ Бојоа $<$ Бојова, Дамч'e:-Нифче < Дамчее $<$ Дамчео $<$ Дамчево) и регресивна (пр.: Велј' $а$ - Чука $<$ Велјаа $<$ Велјоа $<$ Велјова, С'екул К'олиби $<$ Секулии $<$ Секулеи $<$ Секулеви); 
- контракција на вокалите во непосреден допир во дифтонзи, кога вториот вокал е /e/ или /u/ тој преминува во / i/ (пр.: Барл'еiц̧а < Барлеица $<$ Барлевица, Гл'а-и̧a < Глаица < Главица, М'ештро-иุ $<$ Мештроец $<$ Мештровец) или во долги фонови, кога вокалите се исти (пр.: Бунша: Пл'анина < Бушаа < Бушава, Јазо: < Јазоо < Јазово, Јакр'ено: < Јакреноо < Јакреново);

- обезвучување на консонантите во финална позиција (пр.: Дап < Даб, Мерис < Мериз, Pum < Рид, Р'опеш < Ропеж) и во позиција пред безвучен консонант во топонимиските состави (пр.: Зат Падина < Зад Падина, Кр' $и ф-$ Пат < Крив Пат, Пот Кр'ајон < Под Крајон);

- метатеза на групата -вр- во -рв- (пр.: Гарван < Гавран, Гарван'еч$\kappa и$-Дол < Гавранечки Дол) и на групата -ни- во -ин- (пр.: Бран'е-нц̧а < Браненица, Дереп'а-нца < Дерепаница, Опал'е-нц̧а < Опаленица).

5. Морфолошките карактеристики на крушевскиот говор коишто се рефлектирале во топонимијата на Крушевскиот регион може да се проследат преку граматичките категории коишто истовремено важат и за именките. Тоа се следниве именски категории:

- категоријата род, којашто во топонимијата се реализира преку формите за машки (пр.: Р'ебор, Ск'апец, Цуиул), женски (пр.: Бара, Мл'ака, Чука) и среден род (пр.: Б'афче, Гуменцее, Уп'алиште);

- категоријата број, којашто во топонимијата се реализира преку формите за обична (пр.: 'Извори, В'иро- < Вирови, Б'обишта), збирна (пр.: Бр'ак'

- категоријата определеност, којашто во крушевската топонимија формално се реализира преку членските морфеми -от/-та, -то, -те (пр.: C'екот, $K^{\prime}$ 'умкот; но почесто како скратена форма -о: Б'унаро, Змиј'арнико) и -он/-на, -но, -не (пр.: Во Б'укине, Кај Шоп'алоно, Нат Куб'ицине, Пот Кр'ајон);

- категоријата зависност во топонимијата има архаичен статус поради одамнешното губење на падежите од именскиот систем на македонскиот јазик; оваа морфосинтаксичка категорија во крушевската топонимија формално е претставена преку мал број топоними - остатоци од некогашниот генитив (пр.: Гара < именката гар, Ѓума < именката ѓум, Ѓура < личното име Ѓрро, Н'ака < личното име Нако, 'Унка < личното име Унко).

6. Зборообразувачките форманти во крушевската топонимија се директно преземени од апелативното рамниште на македонскиот јазик. Тие, иако имаат формално совпаѓање на двете рамништа, сепак се разликуваат по својата функција во топонимијата. На апелативно рамниште, овие форманти служат за образување збороформи од иста семантичка група (пр.: град - градски - гратче - градиште); додека, пак, на топономастичко рамниште тие служат за создавање имиња со нова содржина. На пр.: именката градиште е аугментативна форма на именката град, а топонимот Гр'адиште 
е топонимизирана форма на истиот апелатив со значење 'место каде што има остатоци од некогашна населба'. Со други зборови кажано, во морфо-синтаксичката анализа на топонимите, најважно е да се утврди кога зборообразувачките форманти имаат функција на топономастички форманти. Оваа разлика особено доаѓa до израз кај топонимите коишто се резултат од супстантивиризачката функција на формантите, пр.: Габ'еро: < Габерово < *Габерово Место < место со габер + -ово, Дабича < *Дабова Шума + -ииа, Мет'ила-и < Метилавеи < *Метилава Ливада + -ец. Од зборообразувачките форманти со топономастичка функција најголема фреквенција имаат именските суфикси -ещ, -ища и -иште, како и придавските суфикси -ов и -ски.

7. Зборовни групи. Во крушевската топонимија именките се најзастапена зборовна група од полнозначните зборови. Веднаш по нив доаѓаат придавките, па глаголите, а поретко броевите и прилозите. Од службените зборови, предлозите се често употребувани како сигнификатори со пространствено значење. Тие претставуваат граматички средства со кои се искажува делумна или прецизна географска ориентација на објектите (локалитетите), на пр.: Во Јазв'ињана, Кај Вод'е-ниите, Кр'ај-Ци̃ква, Н'ад-Јас, По-Река, Пот Петкоец.

8. Синтаксички карактеристики. Синтаксичките карактеристики коишто се рефлектирале во крушевската топонимија се всушност оние карактеристики што се типични за именските фрази во современиот македонски јазик. Тоа се збороредот и конгруенцијата меѓу членовите на повеќекомпонентните топонимиски состави.

Збороредот е синтаксичко средство кое ја определува синтаксичката шема на именските групи и на речениците [Минова-Ѓруркова 2000: 96]. Кај двокомпонентните и повеќекомпонентните топоними во Крушевско тој најчесто е обичен, неутрален и необележен. Тоа значи дека придавката е препозитивно поставена во однос на именката, затоа што таа е носител на дополнителната информација со којашто се определува именката. Имено, ваквиот збороред го претпочита македонскиот јазичен стандард. За разлика од него, во народните говори има појава и на необичен и обележен збороред во именските групи во кои именката е на прво место. Под влијание на крушевскиот говор во топонимијата на Крушевско има појава на извесен број инверзни топонимиски состави, на пр.: Нивата Јофческа, Пато Кривог'аштански, Кај Огр'аѓено Ст'ојкоски, Пр'исојо кај Ч'ивлиго Тасески. Јазичниот стандард инверзните состави ги третира како стилски маркирани, но не и како погрешни.

Конгруенцијата или усогласувањето меѓу елементите на двокомпонентните и повеќекомпонентните топоними се однесува на категориите род и број. Кај овие топонимиски состави се почитува конгруенцијата по род 
и тоа како кај составите $=$ проста придавка + именка, така и кај составите $=$ изведена придавка + именка. Пр.: Малл-Присој (машки род), Голема Леедна (женски род), Стр'едно М'а:ло (среден род) наспроти Гл'ушеф -Рит (машки род), Коле-чин'а-Круша (женски род), Боринско 'Езеро (среден род). Конгруенцијата по род кај овие топонимиски состави е запазена и во инверзните топоними со оваа структура, пр.: Гарот М'ищеф (машки род), Чоб'анища Горна (женски род), Кл'а-нче Ник'олеско (среден род).

И конгруенцијата по број редовно се спроведува кај сите типови на топонимиски состави, пр.: Белан'а-Чешма (еднина), Старин'е-Нивје (множина) наспроти инверзните Гарот М'ицеф (еднина) и Нивјено Томески (множина).

9. Лексиката вградена во крушевската топонимија. Географската местоположба на Македонија била причина за вкрстување на разни цивилизации, култури и јазици во подолг историски пресек. Ова мешање на народите создавало повеќејазични средини со изразена интерференција на македонскиот јазик со други туѓ јазици како: грчкиот, турскиот, албанскиот, ароманскиот и други. Се разбира, македонскиот како централен балкански јазик, покажува најголема јазична интерференција со балканските јазици.

Основна карктеристика на крушевската топонимија е тоа што таа во најголем дел е словенска. Но, ако го земеме предвид фактот дека Крушевскиот регион е еден од посложените етнички и јазични региони во Македонија, тогаш навлегувањето на туѓата лексика не само во говорот, туку и во топонимијата е очекувано. Во неа се забележува паралелна употреба на еквивалентни лексеми од македонскиот и од некој друг несловенски јазик, како на пр.: бигла - стража, тумба - чука, кодра - рид, ќафа - преслап, прој - дол, музга - блато. Во крушевската топонимија се изделуваат неколку лексички слоја.

9.1. Словенска лексика. Најзастапен е словенскиот лексички слој, што покажува дека во овој регион преовладува словенската топонимија. Во него посебно место зазема лексиката наследена од прасловенскиот период, којашто главно е исчезната во современата лексика на македонскиот јазик и во лексиката на месниот говор. Нејзиното зачувување во топонимијата, на топонимите им дава определена архаичност. Такви се лексемите: *arkyta, *dbbrb, *elsha, *koldęzъ, *metъla, *orkyta, *persalpъ, *hvorstb.

Поголем дел од словенската лексика се зборови од старословенскиот слој, коишто се познати во крушевскиот и во другите македонски говори. Овие зборови се составен дел на литературниот јазик, на

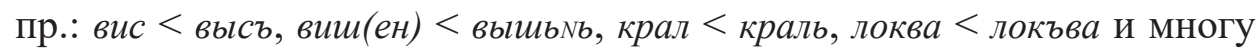
други. 
Посебно место во словенскиот лексички слој претставуваат таканаречените дијалектизми. За дијалектни се сметаат оние лексеми коишто се составен дел од лексичкиот фонд на крушевскиот говор, а поретко се употребуваат во македонскиот литератирен јазик. Еве некои поинтересни примери на дијалектни апелативи во крушевската топонимија: билјак 'гребен', бранеінияа 'шума во која е забрането сечење дрва', вртешка 'кривина на пат', голан 'непошумен рид', градишка 'градина', клокотник 'извор што клокоти', кратища 'покус пат', падија 'падина', седелища 'гнездо'. Се разбира, ова е само дел од дијалектните зборови застапени во топонимијата на Крушевскиот регион. Тие се интересни не само по својата структура, туку и по значењето.

9.2. Несловенска лексика. Од несловенската лексика во крушевската топонимија најзастапени сетурцизмите како дел од балканската лексика. Нивното појавување во топонимијата е во сооднос со влијанието што го има турскиот јазик и во современиот македонски јазик. Овие зборови се интегрирале во сите области од нашата материјална и духовна култура, така што тие денес воопшто не се чувствуваат како туѓи. Се употребуваат напоредно со нивните словенски еквиваленти и ги примаат деривациските морфеми од македонскиот јазик. Во топонимијата на Крушевскиот регион, како и во крушевскиот говор, такви се лексемите: арабаџија, аџија, бавча, бег, бунар, кадија, калдрма, кале, корија, коча, маало, мегдан, нишан, орман, оиа, пазар, сејмен, симит, теќе, ќор, ќош, ќумур, чаир, чардак, чешма, чифлик, иамија и многу други.

Балканските грцизми се лексички слој, кој во македонскиот јазик навлегол главно во средногрчкиот и новогрчкиот период. Како и балканските турцизми, така и балканските грцизми навлегле не само во македонскиот, туку и во други балкански јазици. Во топонимијата на Крушевскиот регион, тие се јавуваат како лексеми коишто се директно преземени од лексичкиот фонд на македонскиот современ јазик. Такви се зборовите: друм, бигла, калуѓер, колиба, ливада, манастир, порта, спила, трпеза, тумба, керамида и други.

Од другите зборови се среќава и мал број романизми. Тоа се зборови со романско, латинско и ароманско потекло. Поради тоа што градот Крушево е населен со значителен број Власи и со Македонци, во топонимијата на градскиот атар се појавуваат и мал број аромански топоними со македонски еквиваленти, како на пример: Арн'аут М'али (аромански) - Арн'аутско М'а:ло (македонски), 'О'хтул Дарбинеш (аромански) - Арна'утски-Рит (македонски), Шоп'атлу а Домн'улуј (аромански) - Господино'а-Чешма. Ароманските топоними имаат ограничена употреба, односно се користат од страна на Власите во нивната меѓусебна комуникација. Затоа, лексиката што учествува во создавањето на ароманските топоними, не треба да биде 
сфатена што влијае врз македонскиот лексички систем. Таа е спорадична појава, којашто е условена од надворешнојазични фактори и има екстралингвистички третман. Во топонимијата на Крушевско се среќаваат следниве балкански романизми: гропа, клисар, пупе, скала, стан, стур, сурин, талар, турте, ума, иуиул.

Влијанието на албанскиот врз македонскиот јазик е незначително. Балканските албанизми се малку на број и нивната употреба е ограничена главно на западномакедонското наречје. Во крушевскиот говор, како и во топонимијата на Крушевскиот регион се јавуваат следните заемки од албанскиот јазик: кодра 'брег, брдо', прој 'дол', ќафа 'превој, премин', чуnа 'мома', шилеже 'сугареч одбиено јагне', шпела 'карпа'. Словенското влијание врз албанскиот јазик е многу поизразено. Тоа се гледа и од многуте примери во топонимијата, каде што се употребуваат словенски зборови наместо соодветните албански. На тој начин се создадени низа хибридни топоними (на пр.: Гур и Кр'алит // К'амено на Крал'и-Марко, Прој и Липес // Липов-Дол, Лед'ина е Маде // Голема Ледина, Клајн'еiции и Ар'ифит // Кл'аінецо на 'Ариф), како и топоними коишто се само фонетски и морфолошки адаптирани на албанскиот јазик (на пр.: Лед'инен // Ледин 'е, Изв'ори и Латес // Латоск'и-Извор, Лив'ади и Б'алес // Б'але: Ливада).

Треба да се истакне дека во топонимијата на северниот и североисточниот дел на Крушевскиот регион, каде што е концентрирано албанското население, најчести се примерите кога словенските топоними по пат на преведување добиле свои албански ликови. Примери: Гур и Дуд'уфит за топ. Дуд'оф-Камен, М'ӑбас К'одре за топ. З'ад-Pum, Тре Ф'аќет за топ. Tp'u-Страни, Вр'име е 'Ујкут за топ. Волиј'а-Дупка, 'Ује и Тарте за топ. Кисел'а-Вода и многу други. Ова преведување на старите и автохтони топоними е присутно во топонимијата на сите региони во Македонија каде што живее албанско население. Во ономастиката оваа појава безрезервно се отфрла како погрешна. Научниот став е категоричен и дециден по ова прашање и тој гласи: не постои превод во ономастиката.

\section{Библиографија}

Божидар Видоески, 1998, Дијалектите на македонскиот јазик, т. 1, Скопје. Влоѓимјеж Пјанка, 1970, Топономастиката на Охридско-преспанскиот базен, Скопје. Лилјана Минова-Ѓуркова, 2000, Синтакса на македонскиот јазик, Скопје. 
Meri Momirovska

\title{
Dialectologycal perspective of the microtoponymy represented through the corpus of Kruszevo region (in the Republic of Macedonia)
}

\author{
(Summary)
}

Main topic of this article is the link between dialectology and local microtoponymy. Microtoponyms are unofficial forms that are not recorded in administrative documents. They have only limited use in local comunities. So they reflect dilectal features of vernacular. The toponyms from Krushevo region contain all features of Krushevo dialect, as: the phonetic, phnological, morphological, lexical and the sintactical one.

Słowa kluczowe: toponimy, mikrotoponimy regionalne, język macedoński, gwara narodowa, przekład.

Key words: toponyms, regional microtoponyms, Macedonian, dialect, translation. 